\title{
Tennis player development: From junior to professional transition stage
}

\author{
Pancho Alvariño, José F. Altur and Miguel Crespo (ESP)
}

ITF Coaching and Sport Science Review 2016; 68 (24): 27 - 30

ABSTRACT

This article justifies the reasons why, in our opinion, the transition from junior to professional is the most important development stage for a tennis player since it will determine his or her future. The development process and plan must be carried out on an ongoing basis, since there is little time, in general, not more than three years. The coach must facilitate the development of the plan with his knowledge and help the player to meet his/her goals in this stage.
Key words: phases, evolution, long term, planning Received: 11 January 2016

Accepted: 11 February 2016 Corresponding author:

Pancho Alvariño

Email: pancho@tennisval.es

\section{INTRODUCTION}

One of the toughest, and at the same time most fascinating tasks of the tennis world occurs when a player with potential "falls" into the hands of the coach who has to plan and programme their career, that is to say, be responsible for their development. The work with young players is a long term job, using a methodology that respects the different evolution stages of the player.

The coaching period is key for players to develop the future skills that are necessary for the physical, mental, technical and tactical qualities to compete safely against all types of players when they reach elite level.

Certainly, this period is getting shorter and shorter. Girls start playing tennis earlier, and often they specialise much earlier than desirable, so they skip many developmental stages. Because of this, it is necessary to go backwards later, and stop their evolution in order to work on what was not done in due time. Besides, the players run the risk of injuries because their bodies are not well prepared to work with greater volumes of physical and psychological loads.

\section{STARTING AGES AND TARGETS}

Some specialists set the appropriate age to begin playing tennis at 5 , because at that age kids already have a better control of their movements. Table 1 summarises the ages top players started playing tennis. It shows that most of them started

between
\begin{tabular}{|c|c|c||c|c|c|}
\hline \multicolumn{5}{c}{ Average tennis starting ages for the top hundred } \\
\hline Rank & Player & Start & Start & Player & Rank \\
\hline 1 & Djokovic & 4 & 7 & Wozniacki & 1 \\
\hline 2 & Nadal & 4 & 6 & Clijsters & 2 \\
\hline 3 & Federer & 8 & 6 & Zvonareva & 3 \\
\hline 4 & Murray & 3 & 7 & Azarenka & 4 \\
\hline 5 & Soderling & 5 & 4 & Sharapova & 5 \\
\hline 6 & Ferrer & 8 & 9 & Li Na & 6 \\
\hline 7 & Monfils & 4 & - & Kvitova & 7 \\
\hline 8 & Fish & 2 & - & Schiavone & 8 \\
\hline 9 & Berdych & 5 & 6 & Bartoli & 9 \\
\hline 10 & Almagro & 8 & 8 & Stosur & 10 \\
\hline 11 & Simon & 6 & 6 & Petkovic & 11 \\
\hline 12 & Roddick & 10 & 7 & Kuznetsova & 12 \\
\hline 13 & Gasquet & 4 & 4 & Radwanska & 13 \\
\hline 14 & Youzhny & 6 & 6 & Pavluchenkova & 14 \\
\hline 15 & Troicki & 5 & 9 & Jankovic & 15 \\
\hline & Average & 5.4 & 6.5 & Average & \\
\hline
\end{tabular}

Table 1. Average starting age for the players ranked in the top 15 in the 2010-2011 season. 
Table 2 summarises the general targets set during each different age in the career of tennis players (boy and girls).

\begin{tabular}{|c|c|c|}
\hline \multicolumn{2}{|c|}{ Objectives during the different ages (boys and girls) } \\
\hline Boys & Age & Girls \\
\hline Begin & $+/-5$ years & Begin \\
\hline $\begin{array}{c}\text { More specific exer- } \\
\text { cises }\end{array}$ & 6 years & $\begin{array}{c}\text { More specific exer- } \\
\text { cises }\end{array}$ \\
\hline Technical work & 9 years & Technical work \\
\hline More demanding training & 11 years & More demanding training \\
\hline$\cdot$ & $14 / 16$ years & First top 10 ranking \\
\hline First top 10 ranking & $16 / 17$ years & - \\
\hline$\cdot$ & 18 years & $\begin{array}{c}\text { Among the top 100 } \\
(622)\end{array}$ \\
\hline $\begin{array}{c}\text { Among the top 100 } \\
\text { (922) }\end{array}$ & 19 years & - \\
\hline$\cdot$ & 21 years & $\begin{array}{c}\text { Greater percentage of } \\
\text { victories no.1 }\end{array}$ \\
\hline $\begin{array}{c}\text { Greater percentage of } \\
\text { victories no.1 }\end{array}$ & 24 years & - \\
\hline Retire & 31 years & Retire \\
\hline
\end{tabular}

Table 2. Targets for tennis players (boys and girls) during the different developmental ages and stages.

Table 3 compares these objectives depending on the development ages and stages with those of Dinara Safina's. It is important to state that these tables are just for guidance, due to the individual nature of tennis, each player has his/her own progression, which can vary considerably depending on the cases.

\begin{tabular}{|c|c||c|c|}
\hline \multicolumn{4}{|c|}{ Dinara Safina general objectives girls/age } \\
\hline Dinara & Age & Age & Girls \\
\hline Beginning & 7 years & $+/-5$ years & Beginning \\
\hline $\begin{array}{c}\text { Trained with her } \\
\text { mother }\end{array}$ & - & 6 years & $\begin{array}{c}\text { More specific } \\
\text { exercises }\end{array}$ \\
\hline $\begin{array}{c}\text { Trained with her } \\
\text { mother }\end{array}$ & 12 years & 11 years & $\begin{array}{c}\text { More demanding } \\
\text { training }\end{array}$ \\
\hline $\begin{array}{c}\text { Age moves to the } \\
\text { academy }\end{array}$ & 14 years & $14 / 16$ years & $\begin{array}{c}\text { First top 10 ranking } \\
(622)\end{array}$ \\
\hline $\begin{array}{c}\text { Won Tarbes } \\
\text { (World under 14) } \\
1 \text { Final 10.000\$ }\end{array}$ & Technical work \\
\hline
\end{tabular}

\begin{tabular}{|c|c|c|c|}
\hline \multicolumn{4}{|c|}{ Dinara Safina general objectives girls/age } \\
\hline Dinara & Age & Age & Girls \\
\hline $\begin{array}{l}\text { Won 1st } \\
\text { \$10,000. Year } \\
\text { end WTA rank } \\
\text { 394. Year end ITF } \\
\text { junior rank no.9 }\end{array}$ & 15 years & 18 years & - \\
\hline $\begin{array}{c}\text { Year end WTA } \\
\text { rank no. } 68\end{array}$ & 16 years & 18 years & $\begin{array}{c}\text { Among the top } \\
100\end{array}$ \\
\hline $\begin{array}{l}\text { Left the acad- } \\
\text { emy }\end{array}$ & 17 years & 19 years & - \\
\hline $\begin{array}{l}\text { Year end WTA } \\
\text { rank no. } 54\end{array}$ & - & 21 years & $\begin{array}{c}\text { Greater percent- } \\
\text { age of victories } \\
\text { no.1 }\end{array}$ \\
\hline $\begin{array}{c}\text { Reaches WTA } \\
\text { no. } 1\end{array}$ & 23 years & 24 years & - \\
\hline $\begin{array}{l}\text { Retires due } \\
\text { to physical } \\
\text { problems }\end{array}$ & 26 years & 31 years & Retire \\
\hline
\end{tabular}

Table 3. Comparison of the objectives of the girls depending on the developmental ages and stages with those of Dinara Safina's.
In the case of players with a future, the coach's priority is.... NOT TO DO THE WRONG THING! That is, not to make mistakes that put the career of a talented player at risk.

If the coach believes in the player, in his/her capabilities as a coach, and has the minimum resources available, the greatest issue for a player not to reach the top positions in the world, is when the coach makes a mistake or makes the wrong decision along the way,

Not to do the wrong thing implies respecting biological rhytm, programming for the long term, planning micro, meso and macro cycles, and anticipating future needs paying attention to the current level.

It is important to remember that not all players who try will become professionals. It is at that point when the coach, as a guide in the process, must be able to detect it in order to avoid frustrated players. Below are some suggestions about things to bear in mind during this stage.

\section{PLAYER PROFILE}

First, it is key to make a player profile, evaluating their conditions and defining their characteristics:

- Technical: basic strokes and natural talent. - Tactical: playing pattern and solutions to win the points. - Physical: endurance, mobility, speed, etc. on-court. - Psychological: motivation, competitiveness. - Previous results: information of competition and level played. This process will help us to know the player's strong and weak points, so as to get all the information possible, to know where we are and where we want to go. The results of these evaluations will provide enough information about the future potential of the player.

\section{GENERAL TRAINING PLAN}

Once the player has been evaluated and we have collated as much data as possible, the next step will be to prepare a general training and competition plan considering the targets we want to reach during those 3 years of work (approximately).

This plan should have the following characteristics:

- Getting resources and funding- enough to cover coaching expenses, competition, travelling, material, accompanying people, medical treatment, etc.

- It must be realistic practical and ordered, with targets for the short, mid and long term.

- It has to be continuous- It should not be interrupted due to the importance of the phase, to the short time available, to the great competitiveness and the need to make decisions and to favour the constant progression and development of the player. Then, it is necessary to make shorter training and competition programmes for the different phases of each season (ex. 4 to 6 weeks). Those programmes must include:

- Technique improvement and consolidation- strokes, intensity, control, strength, direction...

- Playing style- pattern for the conditions of the player.

- Physical conditioning- to improve their physical capabilities and prevent injuries.

- Mental training- concentration training, working habits, control of emotions, etc.

\section{EXERCISES}

Exercise 1

Name: Open the point with an inside-out. Purpose: Tactical work, decision making on when and how to play

inside-out, control strokes from the baseline and play points. Methodology: Rally between players. 
Description: The players rally with cross-court backhands from the baseline. The point will open when one of them can play an inside out. In the next point, the other player will open the point. Variants, volume and intensity: Cross-court backhand from the baseline, this time just using the sliced backhand. The point is open when a player hits inside out. They play cross-court backhands from the baseline and both can change and play down-the-line any time. When its their turn to play inside out, either of them can open the point freely. When changing the down-the-line backhands, if the opponent touches the ball they will win the point. If it is a winner down-the-line backhand, the winner of the point will be the player who played it. (Exercise appropriate for women's tennis).

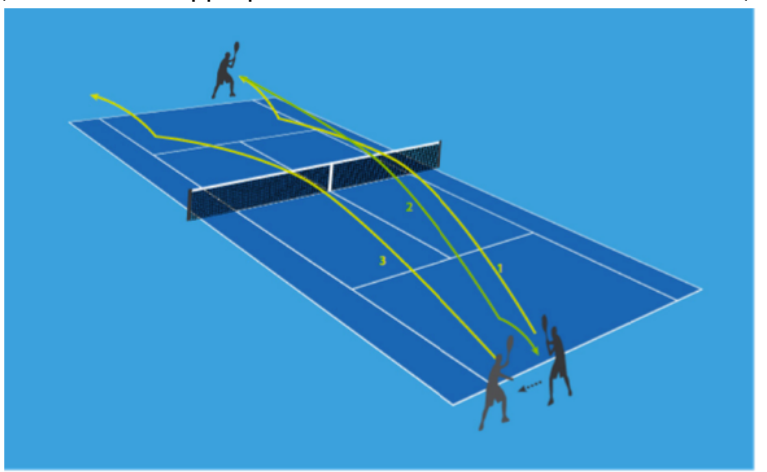

Exercise 2

Name: Short approach ball and volley.

Purpose: Transitions. Adjust the steps to try to hit the short ball as early as possible, to be able to move quickly to the net, so as to cover the court and volley safely.

Methodology: Rally with the coach.

Description: The coach is on one side of the court. They play a short ball and the first player hits a forehand to the coach who will return for the player to volley to the same side. The ball is still in play, the second player comes in doing the same thing, and so on and so forth.

Variants, volume and intensity: It is possible to play long series, looking for volume or shorter series, calling points, in that case, rushing the net to the correct side, but the passing shot and volley are

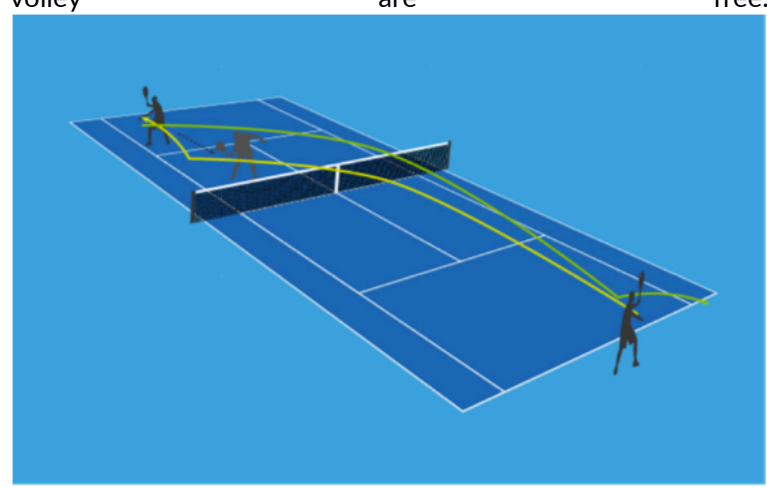

Exercise 3

Name: Playing against yourself. Purpose: Concentration, second service, directions. Methodology: Buckets or basket.

Description: The coach is on one side of the court. They play a short ball and the first player hits a forehand to the coach who will return for the player to volley to the same side. The ball is still in play, the second player comes in doing the same thing, and so on and so forth.

Variants, volume and intensity: It is possible to play long series, looking for volume or shorter series, calling points, in that case, rushing the net to the correct side, but the passing shot and volley are free.

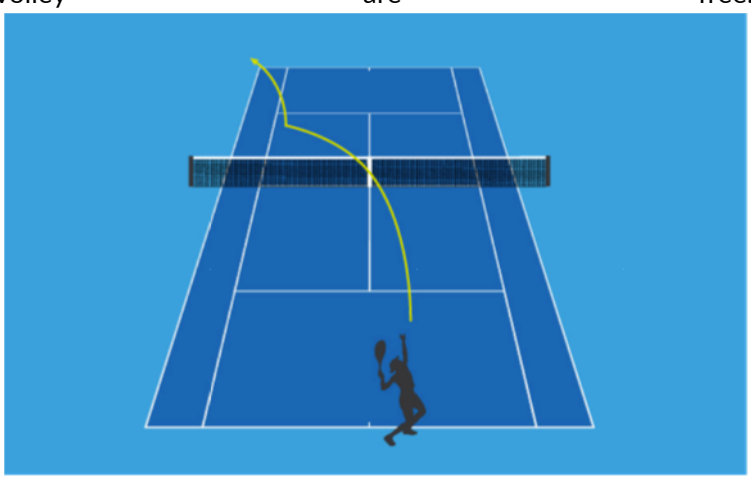

\section{COMPETITION}

After the working period based on previous contents, the player will compete, and for that, it is very important to make an appropriate selection of tournaments according to the competition calendar, which should include:

- Attainable level tournaments- Where the player competes to win, with the pressure that the result is important.

- Higher level tournaments- In order to improve and get familiar with a higher performance level, to be taken as a landmark for progression.

- Valuation of results and ranking- To programme future competition, considering the progression of the player and the importance of going through the upper stages.

\section{CHALLENGES}

All along the player career path, it is necessary to constantly set new challenges. Tennis is a continuous evolution and for this evolutionto happen, players must achieve a polished technique. The better the technique, the more capacity they will have to develop a more versatile tennis game, and the greater options for more appropriate tactics. Initially, to get the first qualification, then, to go on progressing and reach the top 500, then the top 300, 200, 100,70, 50, 20...

When the targets are met, the player must be given new weapons to reach the next target. Here, the player's motivation and ambition are key to work and meet the new targets. When this evolution is interrupted, there is no more progress and the player reaches stagnation and starts declining.

\section{CONCLUSION}

Finally, it is key to insist on the importance of planning, the honesty and communication with the player, and their environment (family, sponsors, federation...) since we are working and coaching youngsters with great potential, talent and dreams.

\section{REFERENCES}

Alvariño, P., Altur, J.F. y Crespo, M. (2015). Tenisval: Filosofía, sistemas de entrenamiento y ejercicios. Valencia. Spain.

Crespo, M., Granitto, G., Miley, D. (2002). Trabajando con jóvenes tenistas. ITF Ltd. Londres.

Fernández-Fernández, J., Méndez-Villanueva, A., Sanz, D. (2012). Fundamentos del entrenamiento de la condición física para jugadores de tenistas en formación. RFET. Barcelona.

Reid, M., Quinn, A., Crespo, M. (2003). Fuerza y condición física para el tenis. ITF Ltd. London.

Roetert, P., Ellenbecker, T. (2008). Preparación física completa para el tenis. Tutor. Madrid. 
RECOMMENDED ITF TENNIS ACADEMY CONTENT (CLICK BELOW)

$$
\text { TTF Academy }
$$

Copyright (c) Pancho Alvariño, José F. Altur and Miguel Crespo 2016
This text is under a Creative Commons BY 4.0 license

You are free to Share - copy and redistribute the material in any medium or format - and Adapt the content - remix, transform, and build upon the material for any purpose, even commercially under the following terms:

Attribution: You must give appropriate credit, provide a link to the license, and indicate if changes were made. You may do so in any reasonable manner, but not in any way that suggests the licensor endorses you or your use. 